\title{
Identification of near-surface saline water in the Lake Kelemenszék area, Danube-Tisza Interfluve, Hungary
}

\author{
Szilvia Simon, Judit Mádl-Szőnyi, \\ Department of General and Applied Geology \\ Eötvös Loránd University, Budapest
}

\author{
Imre Müller, Ferenc Zsemle \\ Department of General and Applied Geology \\ Eötvös Loránd University, Budapest
}

\begin{abstract}
In the Danube Valley, a chain of saline lakes and a salinized area are situated in the discharge zone of two different waters. The two watertype were followed till the near surface by regional chemical and hydraulic investigations (Mádlné Szónyi and Tóth 2009). The goals of this study were to prove the presence of these different waters in the near surface zone around the Lake Kelemenszék, and allocate their connection to the lake and to the salinized ground surface. Near-surface geophysical measurements (VES, RMT) supported the regional hydraulic and chemical results. The sediments are saturated by saline water down to $110 \mathrm{~m}$ beneath the lake, and to the east the fresh water is prevalent. The local chemical investigations strengthened this distribution. Highly saline water with $\mathrm{Na}-\mathrm{HCO}_{3}-$ Cl-type discharges into and around the lake. To the east there is a continuous change towards a $(\mathrm{Ca}, \mathrm{Mg})-\left(\mathrm{HCO}_{3) 2}\right.$-type fresh water discharge. The interface between the two water types is a $2-3 \mathrm{~km}$ wide transition zone. The results of the investigations proved that the saline water of the deep flow system rises to the surface and provide salt for the salinization of the area.
\end{abstract}

Key words: surface geophysics, electric resistivity, saline and fresh water, chemical facies analysis, Lake Kelemenszék Area

\section{Introduction}

Lake Kelemenszék is situated in a N-E directed, highly salinized wetland area of the Danube Valley (Fig. 1). This lake is the southernmost one of a chain of saline lakes in the valley. According to previous investigations (Mádlné Szónyi et al. 2005; Mádl-Szőnyi and Tóth 2009) Lake Kelemenszék is located in a "hydraulic window", meaning the discharge of a higher-scale or distantly originating flow system. This discharge constitutes the so-called "window" between other

Addresses: Sz. Simon, J. Mádl-Szőnyi, I. Müller, F. Zsemle: H-1117 Budapest, Pázmány P. stny 1/C, Hungary, e-mail: szilvia.simon@gmail.com

Received: September 1, 2008; accepted: October 27, 2008 


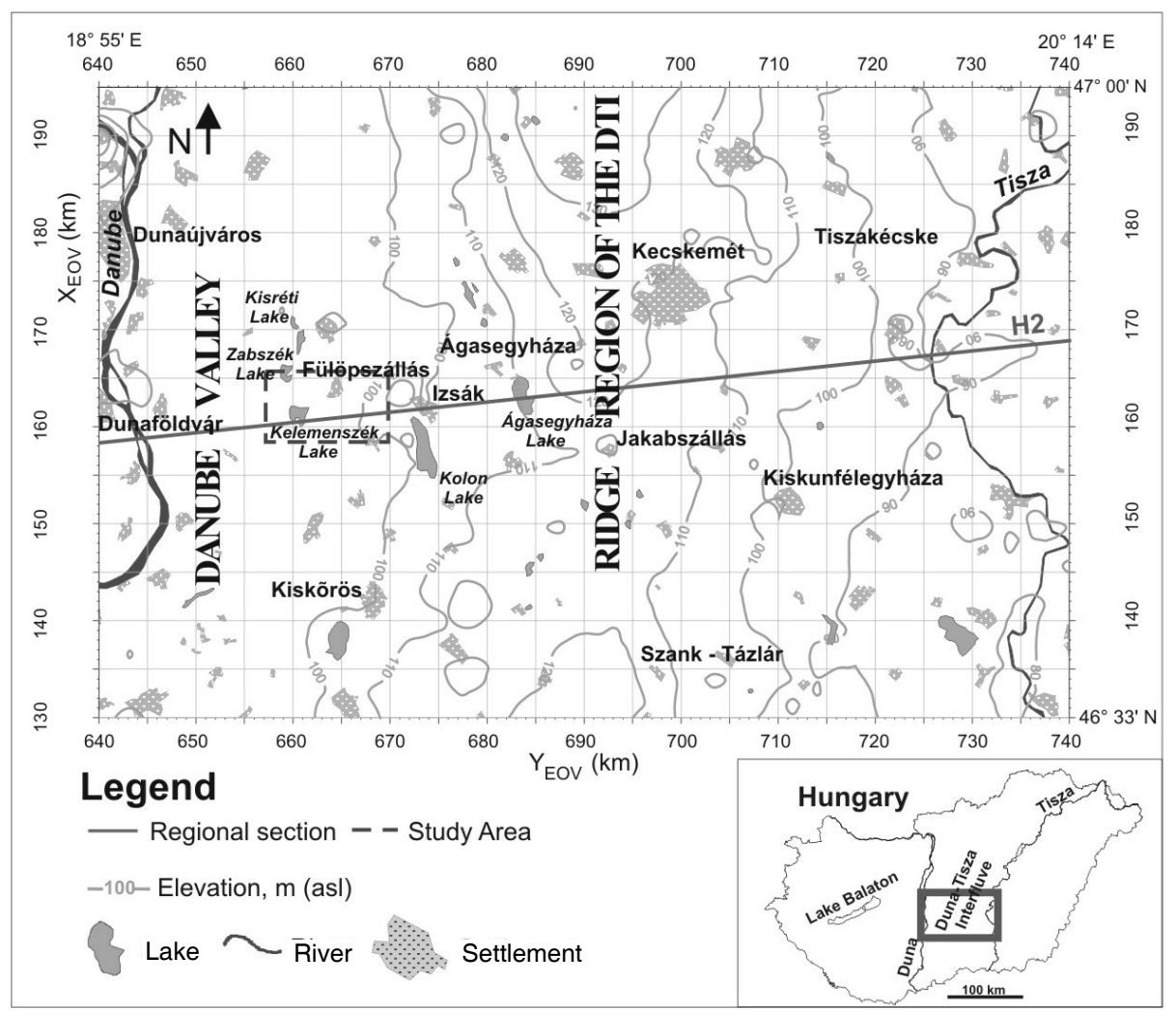

Fig. 1

The Study Area (SA) and its surroundings

hierarchically nested, overlying flow systems (Engelen and Kloosterman 1995, p. 7). The lake and its surroundings are assumed to receive the discharge of two different waters: saline water of deep provenance and fresh water infiltrating from the ridge region of the Danube-Tisza Interfluve (DTI) (Fig. 1) (Mádl-Szônyi and Tóth 2009). The saline water discharge is considered to be the source of the salinity content of the lake and the soils in the area. The interface between the different water types is assumed to be located in the eastern part of the lake (Mádl-Szőnyi and Tóth 2009).

The goals of this study were the following:

i) to confirm the existence of the hydraulic window in and around the lake;

ii) to reveal the presence of saline pore water in the near surface sediments in the surroundings of the "window",

iii) to show the hydrogeochemical contrast of this discharge with the surrounding water-environment; and 
iv) to document the hydrochemical interaction between the saline as well as the fresh water discharge and the lake. To answer these questions, field work, shallow geophysical measurements and local chemical sampling were carried out in the Study Area, i.e. in the vicinity of the lake (Fig. 1).

The identification of near surface saline water at Lake Kelemenszék was based on the distinct chemical character of the discharging waters at the area. The deep, overpressured water in the Pre-Neogene basement has a TDS of 10000-38000 $\mathrm{mgL}^{-1}$ as well as high $\mathrm{Cl}^{-}\left(8000-15000 \mathrm{mgL}^{-1}\right)$ and $\mathrm{Na}^{+}\left(6000-10000 \mathrm{mgL}^{-1}\right)$ contents. It belongs to the $\mathrm{NaCl}$ hydrogeochemical facies type (Mádl-Szônyi and Tóth 2009). Beneath the Study Area the Pre-Neogene basement rises up to $800 \mathrm{~m}$ below ground surface. Above this part of the basement the principally upwelling $\mathrm{NaHCO}_{3}$-type water of Neogene basin sediments sporadically also has a high $\left(>100 \mathrm{mgL}^{-1}\right) \mathrm{Cl}^{-}$-content. In the Study Area these waters fill the sediments between the meridian YEOV=664 km and the Danube River (Fig. 1). The meteoric, gravity-driven fresh calcium-bicarbonate type water of the ridge region is characterized by maximum $500 \mathrm{mgL}^{-1} \mathrm{TDS}$ and 3-30 $\mathrm{mgL}^{-1} \mathrm{Cl}^{-}$-content (MádlSzônyi et al., this volume; see also Fig. 8 therein). The cited figure shows, based on archive chemical data interpretation, that the highest TDS and $\mathrm{Cl}^{-}$values characterize the groundwater beneath the lake. These values continuously decrease eastward. The above-mentioned distinct chemical features, considering mainly the TDS and $\mathrm{Cl}^{-}$-content of the discharging waters at Lake Kelemenszék, were used as "natural chemical tracers" to address the issues of the recent study.

\section{Approaches and Methods}

To detect and distinguish the two different water types in the vicinity of the lake and in the lake water, geophysical measurements and chemical sampling were carried out. With the help of shallow resistivity methods (taking the lithological composition into consideration) the different salt contents of pore water could be detected. The specific resistivity values depend on the material of the rock matrix and also on the salinity of pore water. In the Study Area the uppermost $\sim 100 \mathrm{~m}$ thick strata are bedded subhorizontally. In this case, for a given layer the horizontal resistivity differences are caused by differing electric conductivity, i.e. the different total dissolved solid contents of the pore water Smaller resistivity values signify a higher TDS content. In this way the spatial distribution of the different water types with various TDS could be detected.

In the course of the surface geophysical investigation, electric (VES, Vertical Electric Sounding) measurements (penetration depth for the area: 100-120 m) and Radio-Magneto-Telluric (RMT) (Turberg et al. 1994; Stiefelhageln 1998) survey (actual penetration depth: 18-25 m) were applied (Fig. 2). In the case of the VES measurements, Schlumberger arrays were applied with maximum $\mathrm{AB} / 2=200 \mathrm{~m}$ distance. In the course of the RMT measurements three frequencies 


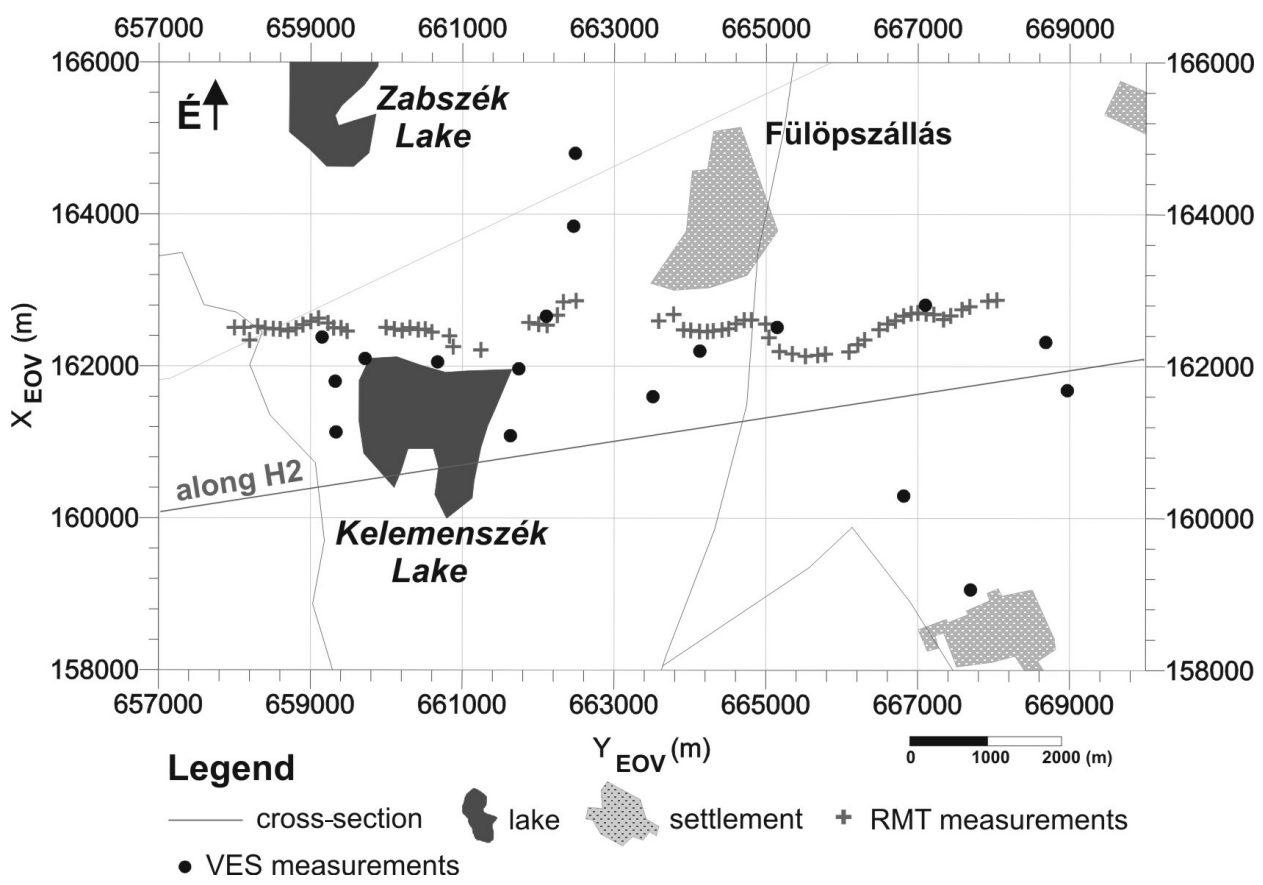

Fig. 2

Map of shallow resistivity measurements

$(234 \mathrm{kHz}, 77.5 \mathrm{kHz}$ and $22.1 \mathrm{kHz}$ ) were used to detect the resistivity at three different depths.

From the apparent resistivity values $\left(\rho_{\mathrm{a}}\right)$ of VES the subsurface resistivity distribution was calculated with the help of two computer programs: PISE (of the Geophysical Department of the Université VI of Paris) and Schlumberger (improved at Center for Hydrogeology, University of Neuchâtel, Switzerland). In this way we obtained the layer thickness values and resistivity values as functions of the pore water electrolyte conductivity (Erdélyi and Gálfi 1988).

In the case of the RMT the two measured parameters allowed data interpretation based on Magneto-Tellurics (MT) to calculate specific resistivitydepth distribution (Fischer et al. 1981).

The sampling sites for chemical analysis are situated on the area of the hydraulic, i.e. the supposed "hydrochemical window" and in the "mixing zone" (Figs 3 and 4). Samples were taken from the water of twenty wells dug to depths of 3-4 m and five (5, 10 and $20 \mathrm{~m}$-deep) observation wells. The lake and the surrounding channels were also sampled.

Sampling was carried out between March 2005 and October 2007. The samples were collected every three weeks from the observation wells and the lake, and seasonally from the dug wells. $\mathrm{Ca}^{2+}, \mathrm{Mg}^{2+}, \mathrm{HCO}_{3}{ }^{-}$were analyzed by acid-base 


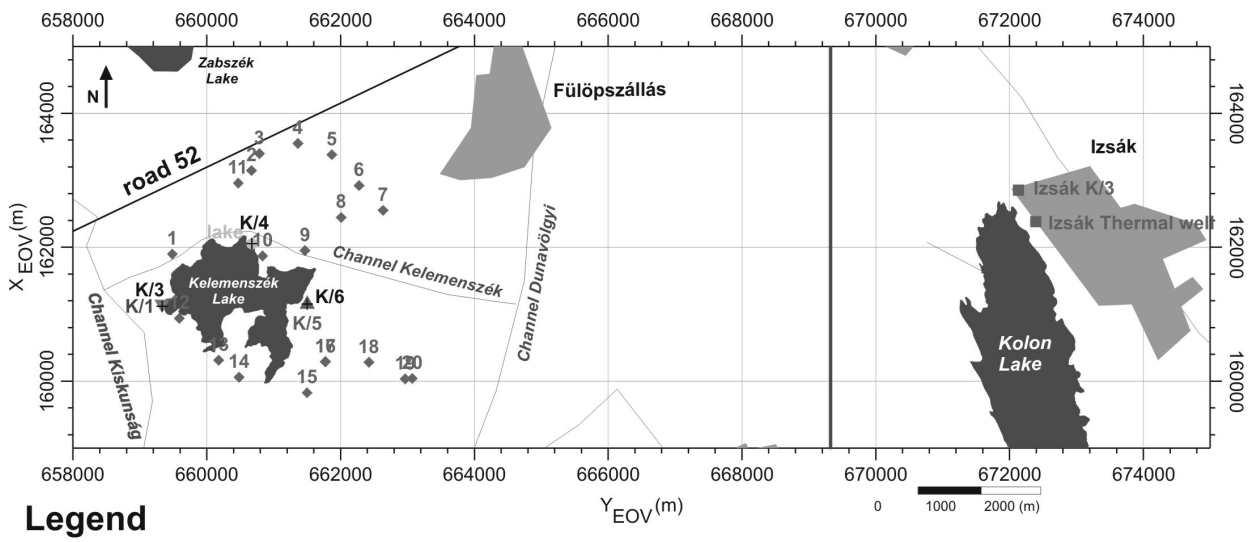

- (1-20) dug wells $\quad(\mathrm{K} / 1) 5 \mathrm{~m}$ deep observation well $+(\mathrm{K} / 3, \mathrm{~K} / 4, \mathrm{~K} / 6) 10 \mathrm{~m}$ deep observation wells

$\triangle(K / 5) 20$ m deep observation well - lake_channel settlement \& lake _ highway

- reference wells at Izsák _ boundary of the Study Area

Fig. 3

Water sampling sites on the Study Area and reference wells at Izsák

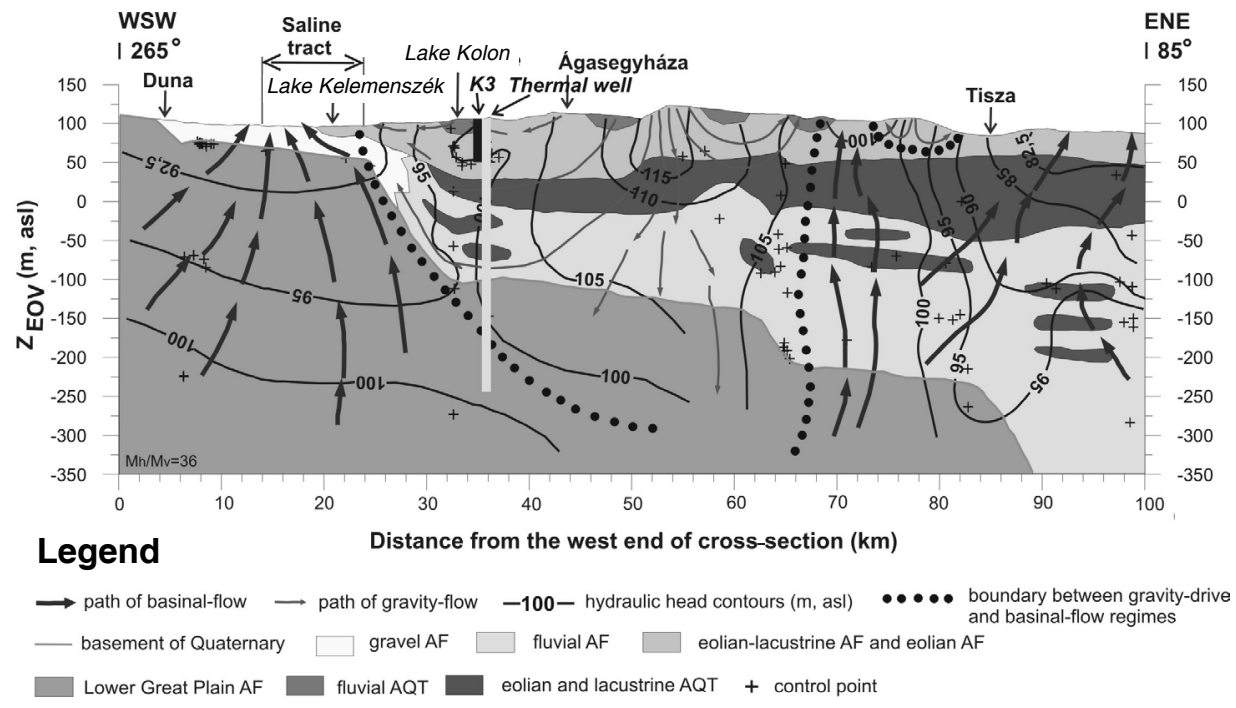

Fig. 4

Reference wells (K/3 and Thermal well) at Izsák displayed on the Shallow Regional Hydrostratigraphic and Hydraulic Section of Mádl-Szőnyi and Tóth (2009) 
titration methods, $\mathrm{Cl}^{-}$by complexometric titration. $\mathrm{Na}^{+}$and $\mathrm{K}^{+}$were detected by flame photometry, and $\mathrm{SO}_{4}{ }^{2-}$ by photometry.

For the interpretation average data were used. To follow the discharging waters of distinct origin in the Study Area, two reference wells were used. These wells were selected based on regional hydraulic (Mádl-Szőnyi and Tóth 2009) and local salinization studies (Mádl-Szőnyi et al., this volume) of the Danube-Tisza Interfluve. The waters of the reference wells are supposed to represent the "fresh" (Izsák K/3) and "saline" (Izsák, Thermal well) flow branches, i.e. the meteoric infiltrated gravity-driven $(\mathrm{Ca}, \mathrm{Mg})-\left(\mathrm{HCO}_{3}\right)_{2}$ water and the upwelling mixed water of basinal ( $\mathrm{NaHCO}_{3}$-type) and basement (NaCl-type) origin (Figs 3 and 4). With the help of this analysis the origin and the connection of the shallow groundwater and lake water were examined in the Lake Kelemenszék Study Area.

\section{Geophysical Results}

RMT measurements (grey crosses in Fig. 2) were carried out along a section, almost parallel to the Local Hydrostratigraphic-Hydraulic and Water Salinity Section (H2) of Mádl-Szônyi et al. (this volume, Figs 6 and 8). VES measurements (black dots 1n Fig. 2) were taken in the vicinity of existing boreholes and wells, from which detailed lithological data were available. The resistivity values of the two methods were represented on the Lithological Section which was recorded along the Local Section of Mádl-Szőnyi et al. (this volume, Fig. 6) between km 11.350 and 24.000. The original section was modified: instead of hydrostratigraphic units, lithological units were shown, compiled from archive borehole data near the VES measurements. Archive data thus allowed us to reliably separate the effect of lithology and pore water salinity on both data sets during interpretation.

Specific resistivity values (black numbers in italics) in Figs 5, 6, and 7 refer to fresh water (TDS $<500 \mathrm{mgL}^{-1}$ )-saturated rock matrix and were taken from the literature (Erdélyi and Gálfi 1988; Fig. 6.1 on p. 85). The specific resistivity values are shown by isolines in Figs 5, 6, and 7 .

The calculated RMT values (20-30 $\Omega \mathrm{m})$ are systematically smaller than the black numbers in italics representing the fresh water-filled strata beneath the lake (Fig. 5). These low resistivity values are proven down to the depth of $\sim 20 \mathrm{~m}$, in the silt layer, and in the underlying gravel (the lightest yellow layer) as well. Eastward the calculated values increase $(50-70 \Omega \mathrm{m})$ and reach the fresh water values from the literature.

The VES measurements (Fig. 6) reveal the same specific resistivity trend in $\mathrm{E}-\mathrm{W}$ direction as the RMT values, but also for the deeper part of the section. In all layers to the west of the supposed boundary of the two hydraulic systems, lower specific resistivity values (6-25 $\Omega \mathrm{m})$ than expected were registered for fresh water-saturated sediments. The greatest differences between the measured (6-25 


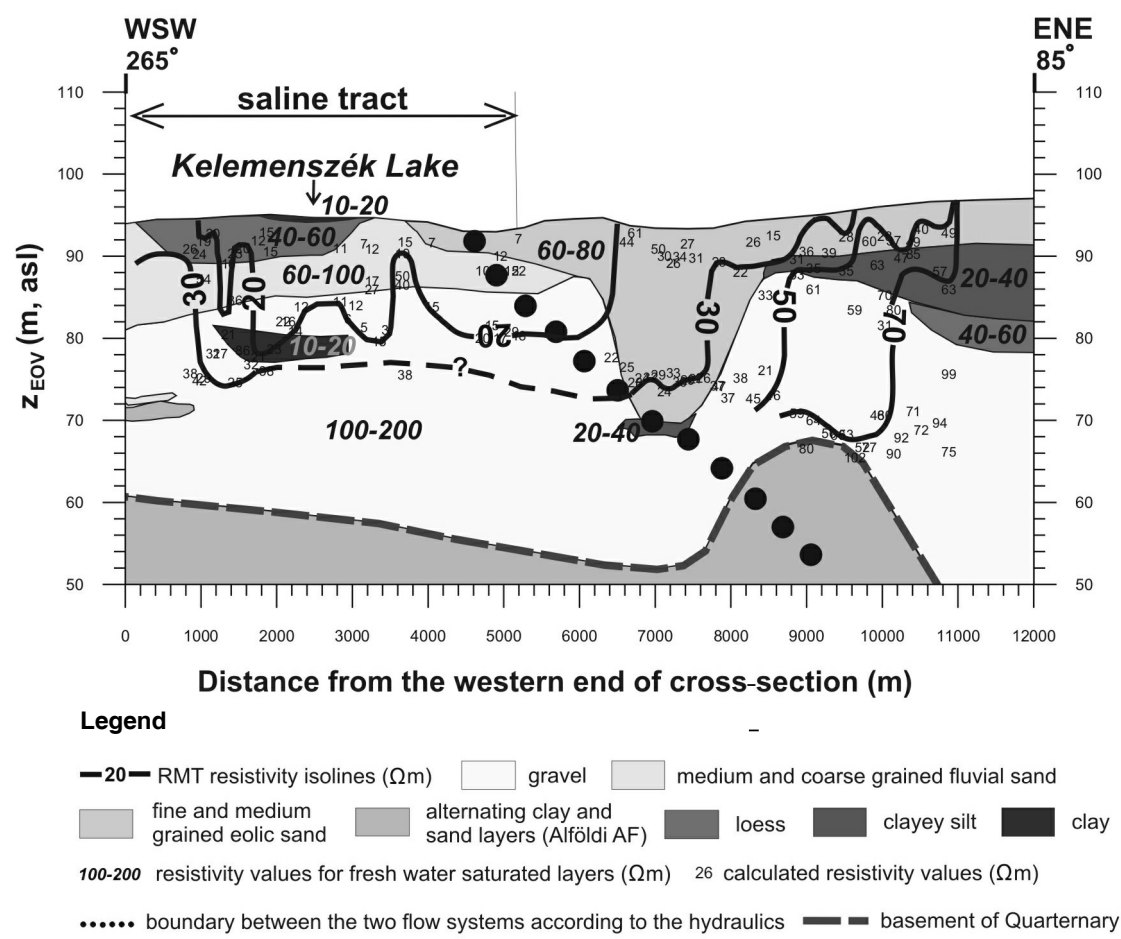

Fig. 5

Interpreted RMT data (isolines; black numbers refer to fresh water saturation), displayed along the Lithological Section

$\Omega \mathrm{m})$ and fresh water-saturated (100-200 $\Omega \mathrm{m}$ ) strata values were again found in the gravel layer, indicated by the lightest grey color in Fig. 6 . This anomaly can be followed in every layer to a depth of $\sim 100 \mathrm{~m}$, indicating the presence of highly saline groundwater. To the east, resistivity values became gradually higher (30-70 $\Omega \mathrm{m})$, finally reaching the values characteristic for fresh water-filled gravel. This means that the salinity of the groundwater decreases eastward.

\section{Interpretation}

The results of the RMT and VES measurement distribution of specific resistivity values show good agreement in the upper $25 \mathrm{~m}$ (Fig. 7). VES data show that highly saline water fills the pores in the surroundings of the lake from the ground surface to a depth of $\sim 100 \mathrm{~m}$, whereas "fresh water" of the gravity system dominates in the eastern part of the area. The $30 \Omega \mathrm{m}$ resistivity value characterizes the boundary between the "saline" and the "fresh" water. As shown in Fig. 7 this boundary does not represent a sharp contact between the flow regimes, but rather a gradual transition, a "mixing zone" covering a distance of $\sim 2-3 \mathrm{~km}$. 


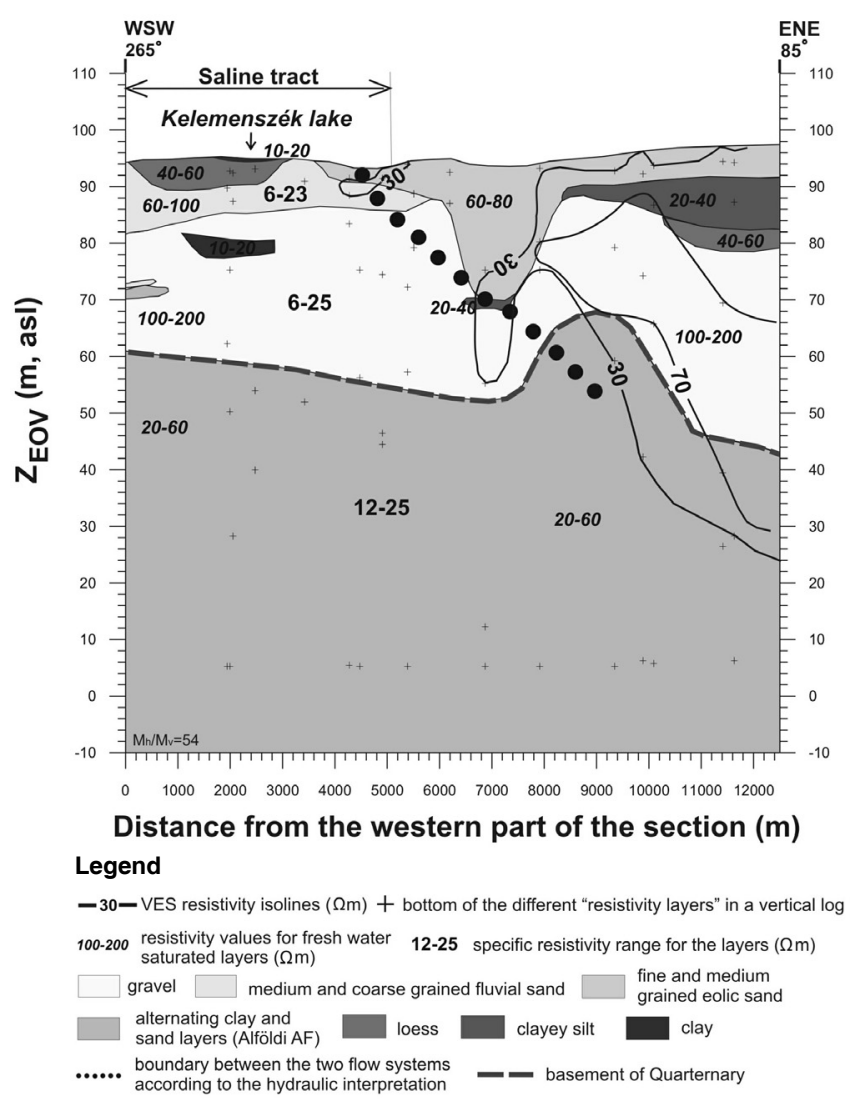

Fig. 6

VES data interpretation (isolines; black numbers refer to fresh water saturation), displayed along the Lithological Section

\section{Chemical Results}

To support the results of geophysical measurements the chemical composition of the shallow groundwater was examined in the Study Area (Fig. 1). Two reference wells representing the composition of the fresh, gravity-driven water (Izsák K/3; depth: $52.5 \mathrm{~m}$ ) and the upwelling mixed saline water (Izsák Thermal well; depth: $370 \mathrm{~m}$ ), respectively, were used for the interpretation (Figs 3 and 4).

The Izsák thermal well has NaCl-type water (TDS: $2189 \mathrm{mgL}^{-1} ; \mathrm{Na}^{+}: 635.0$ $\mathrm{mgL}^{-1}, 27.61 \mathrm{meqL}^{-1}, 96.54$ percent equivalent $(\% \mathrm{e}) ; \mathrm{Cl}^{-}: 379 \mathrm{mgL}^{-1}, 10.6 \mathrm{meqL} \mathrm{L}^{-1}$, $37.44 \% \mathrm{e}$ ), while the water of the other reference well, the Izsák $\mathrm{K} / 3$, is of the calcium-magnesium-bicarbonate type (TDS: $400.0 \mathrm{mgL}^{-1}$, Ca: $57.3 \mathrm{mgL}^{-1}, 2.9$ meqL ${ }^{-1}, 52.92 \% \mathrm{e} ; \mathrm{Na}^{+}: 9.5 \mathrm{mgL}^{-1}, 0.41 \mathrm{meqL}^{-1}, 8.87 \% \mathrm{e} ; \mathrm{HCO}_{3}: 275 \mathrm{mgL}^{-1}, 4.51$ meqL ${ }^{-1}, 87.00 \%$ e; $\left.\mathrm{Cl}^{-}: 14.7 \mathrm{mgL}^{-1}, 0.414 \mathrm{meqL}^{-1}, 10.48 \% \mathrm{e}\right)$. 


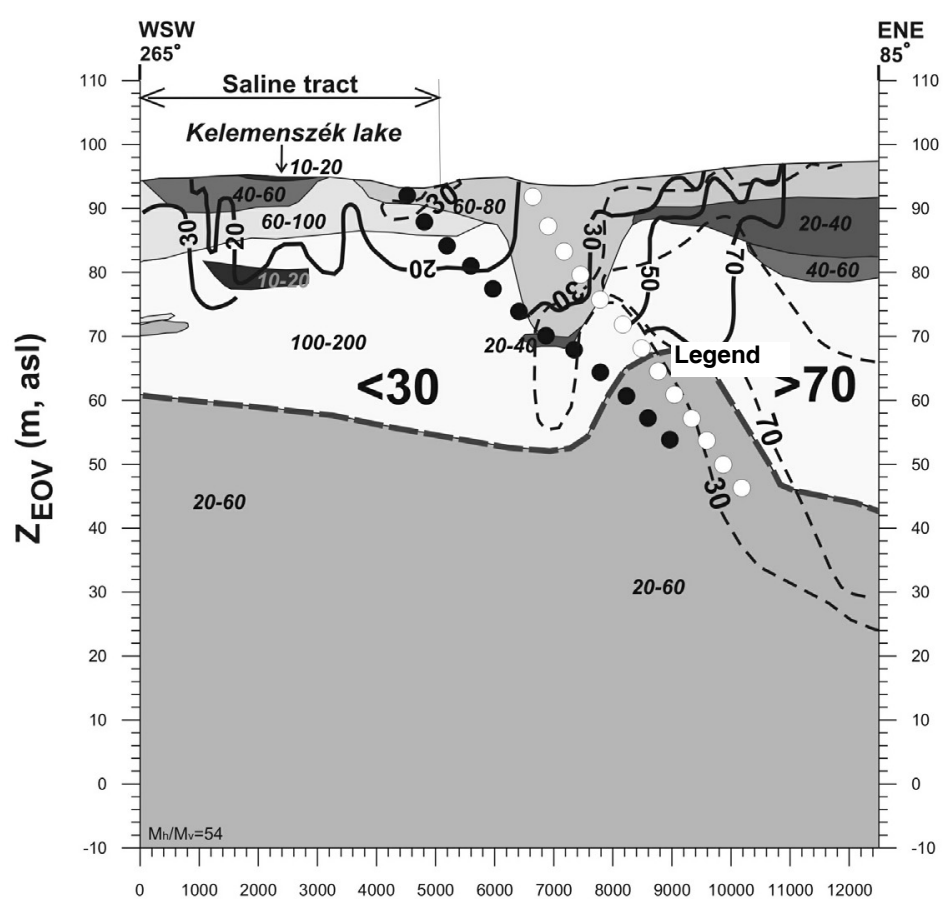

$$
\begin{aligned}
& \text { Distance from the western part of the section (m) } \\
& \text { Legend } \\
& --30-- \text { VES resistivity isolines }(\Omega \mathrm{m})-20-\text { RMT resistivity isolines }(\Omega \mathrm{m}) \\
& 100-200 \text { resistivity values for fresh water saturated layers }(\Omega \mathrm{m})-- \text { basement of Quarternary } \\
& \ldots . . . \text { boundary between the two flow systems according to the geophysical measurements } \\
& \ldots . . . \text { boundary between the two flow systems according to the hydraulic interpretation } \\
& \square \text { gravel } \square \text { medium and coarse grained fluvial sand } \\
& \text { alternating clay and } \\
& \text { sand layers (Alföldi AF) }
\end{aligned}
$$

Fig. 7

Composite interpretation of RMT and VES data, displayed along the Lithological Section

The measured averages of main cations and anions for each sampling site were displayed in percentage of meqL-1 values on the Piper plot (Fig. 8). In the figure two water types can be distinguished. The smallest group contains the water of the Izsák K/3 reference well and the channels, with calcium-magnesiumbicarbonate facies, representing the gravity-driven meteoric water (black, dashed line circle in Fig. 8). The larger group includes the Izsák thermal well and the wells around the lake with water of $\mathrm{Na}-\mathrm{HCO}_{3}-\mathrm{Cl}$ facies, which shows a mixing of the deep $\mathrm{NaCl}$-type water and the $\mathrm{Na}-\mathrm{HCO}_{3}$-type water of the Neogene sediments (black, dotted line circle in Fig. 8). 


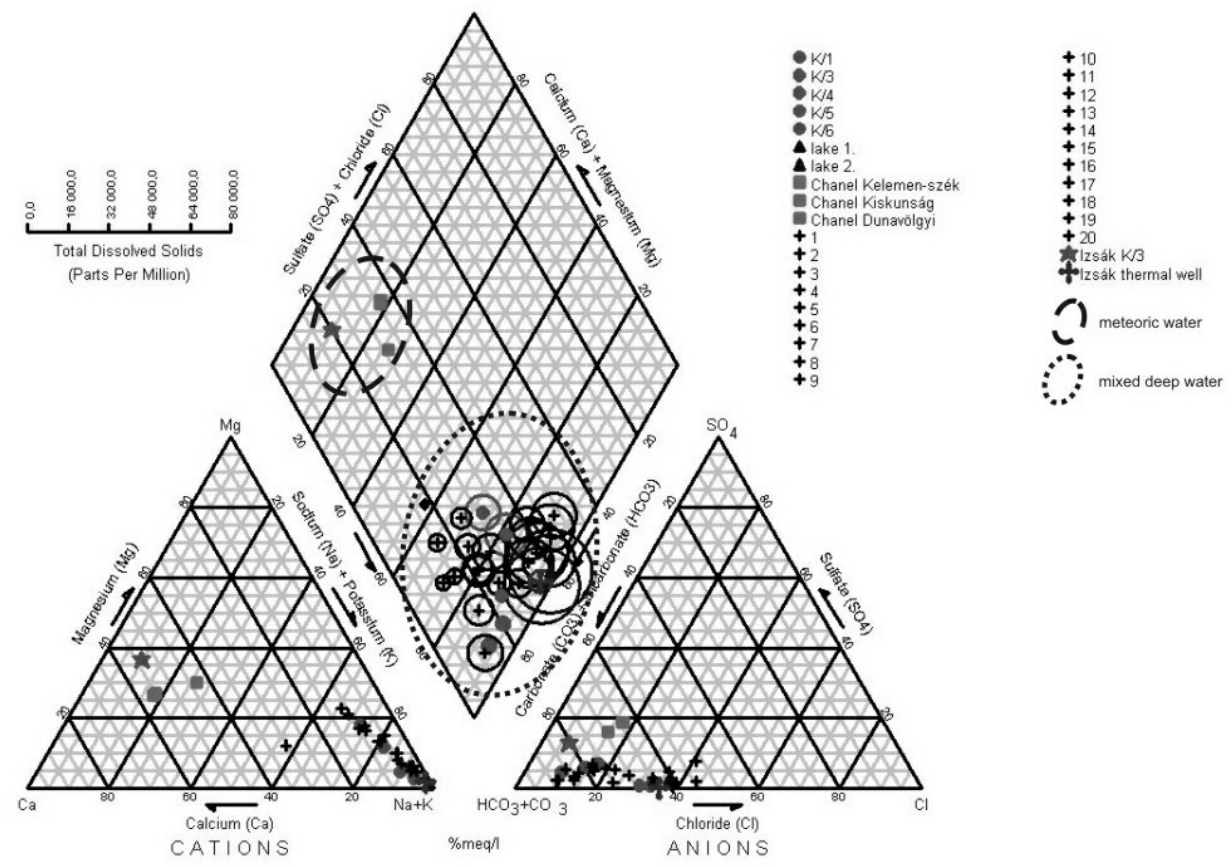

Fig. 8

Piper plot of the average values of main cations and anions for every sampling site, displayed in percentage of meqL ${ }^{-1}$

Examining the data in greater detail it can be observed that the TDS content of the dug and shallow observation wells is the highest in a N-S directed zone through the lake (TDS: $4172 \mathrm{mgL}^{-1} ; \mathrm{Na}^{+}: 1297 \mathrm{mgL}^{-1}, 56.3 \mathrm{meqL}^{-1}$; Cl-: 855 $\left.\mathrm{mgL}^{-1}, 24.0 \mathrm{meqL}^{-1}\right)$; the values decrease outwards from the lake both to the east and to the west. The deeper observation wells $(10$ and $20 \mathrm{~m}$ ) provide water samples of a slightly different chemical composition. For the water of the $\mathrm{K} / 1 \mathrm{~K} / 3$ $\mathrm{K} / 4$ (10 m-deep) wells (Fig. 3) the main cation is $\mathrm{Na}^{+}\left(300-360 \mathrm{mgL}^{-1}\right)$ and the TDS content is $1000-2500 \mathrm{mgL}^{-1}$. The values of $\mathrm{K} / 4$, to the north of the lake (Fig. 3 ), are always lower (TDS: $\sim 1000 \mathrm{mgL}^{-1}$ ) compared to the others. Wells $\mathrm{K} / 5$ and $\mathrm{K} / 6$, on the eastern shore of the lake, have higher $\mathrm{Cl}-\left(500-670 \mathrm{mgL}^{-1}, 18.63\right.$ $\left.\mathrm{meqL}^{-1}, 33.46 \% \mathrm{e}\right)$ and TDS (3000-4000 $\mathrm{mgL}^{-1}$ ) values than the others, and beside $\mathrm{Na}^{+}\left(750-1100 \mathrm{mgL}^{-1}, 33.1-48.1 \mathrm{meqL}^{-1}, 71.75-82.11 \% \mathrm{e}\right)$ the $\mathrm{Mg}^{2+}(82-104$ $\left.\mathrm{mgL}^{-1}, 6.8-8.6 \mathrm{meqL}^{-1}, 11.52-18.59 \% \mathrm{e}\right)$ and $\mathrm{Ca}^{2+}\left(71-86 \mathrm{mgL}^{-1}, 3.5-4.3 \mathrm{meqL}^{-1}\right.$, 6.02-9.23\% e) contents are also considerable. The lake water (TDS: 8000-9200 $\mathrm{mgL}^{-1} ; \mathrm{Na}^{+}: 2100-2300 \mathrm{mgL}^{-1}, 100$ meqL ${ }^{-1}, 97.71 \% \mathrm{e} ; \mathrm{Cl}^{-}: 1100-1300 \mathrm{mgL}^{-1}, 36$ meqL $\left.\mathrm{L}^{-1}, 38.44 \% \mathrm{e}\right)$ is of almost the same chemical facies as the Izsák Thermal well, with higher TDS. 


\section{Interpretation}

The above-mentioned distribution of the measured data on the Study Area can be deduced from the discharge of the saline and fresh water, hydrogeochemically represented by the reference wells. Water samples of the shallow and the deeper observation wells surrounding the lake indicate the presence not only of a hydraulic but also a "hydrogeochemical window", i.e. $\mathrm{Na}-\mathrm{HCO}_{3}$-Cl-type water discharge. This water is allochthonous and feeds the lake from underground. Its chemical composition is approximately identical with the water of the Izsák thermal well. On the eastern side of this window fresh water discharge occurs. Between these zones at the interface mixing and dispersion seem to be the main controlling factors. This mixing is defined by continuously changing chemical composition from the lake toward the east from $\mathrm{Na}-\mathrm{HCO}_{3}$-Cl-type to $(\mathrm{Ca}, \mathrm{Mg})$ $\left(\mathrm{HCO}_{3}\right)_{2}$-type. The discharge center is in the lake and the shallow wells can be traced by the highest TDS values. According to this interpretation the effect of the saline water discharge must dominate most strongly at the $\mathrm{K} / 5$ and $\mathrm{K} / 6$ observation wells, which is supported by their highest $\mathrm{Cl}$ - content, while the presence of $\mathrm{Ca}^{2+}$ and $\mathrm{Mg}^{2+}$ shows the effect of the contribution of the "fresh water" flow system.

In addition, close to the surface, evaporation and other local effects can also modify the chemical composition. This is shown in the $\mathrm{K} / 4$ well, the water composition of which shows the diluting effect of the Kelemenszék Canal (Fig. 3).

\section{Summary}

The results of the near-surface geophysical (RMT, VES) and hydrogeochemical facies investigations supported the hydraulically-based hypothesis of the existence of a "hydraulic and hydrogeochemical window" at Lake Kelemenszék. The measurements and analyses proved that highly saline $\left(\rho_{\mathrm{s}}:<30 \Omega \mathrm{m}\right.$; TDS: $\left.\sim 4000 \mathrm{mgL}^{-1}\right) \mathrm{Na}-\mathrm{HCO}_{3}$-Cl-type water discharges into and around the lake. The boundary of the "window" is not sharp; on its eastern side there is a continuous change toward fresh water $\left(\rho_{\mathrm{s}}:>70 \Omega \mathrm{m}\right.$; TDS: $\left.<500 \mathrm{mgL}^{-1}\right)(\mathrm{Ca}, \mathrm{Mg})-\left(\mathrm{HCO}_{3}\right)_{2^{-}}$ type discharge. In this allochthonous discharge, close to the surface evaporation and other local effects can also modify the chemical composition. The dissolved solid content of the discharging saline water rises toward the surface, and provides salt for the lake and the sodic soils.

The RMT and VES methods, as well as chemical facies analysis are powerful tools to examine allochthonous near-surface water discharge. The results of this study, beside its scientific merit, have practical importance from the point of view of amelioration of sodic soils, water management of the region and the protection of saline wetlands. 


\section{Acknowledgements}

The authors thank Prof. J. Tóth, Prof. I. Varsányi and Dr. L. Lenkey for their help in the course of this work. The research was supported by Dataqua Elektronikai Ltd. and by the financial support of the Hungarian National Science Foundation grant of J. Mádl-Szônyi (T 047159). This research forms part of the PhD study of Sz. Simon and is based on the MSc Thesis of Zs. Tóth (2007).

\section{References}

Engelen, G.B., F.H. Kloosterman 1995: Hydrological Systems Analysis. Methods and Applications. Water Science and Technology Library, 20, Kluwer Academic Publishers.

Erdélyi, M., J. Gálfi 1988: Subsurface and Surface Mapping in Hydrogeology. - John Wiley and Sons, Academic Press, Budapest.

Fischer, G., P.A. Schnegg, M. Peguiron, B.V. Le Quang 1981: An analytic one dimensional magnetotelluric inversion scheme. - Geophysical Journal of the Royal Astronomical Society, 67, pp. $257-278$

Mádl-Szőnyi, J., J. Tóth 2009: A hydrogeological type section for the Duna-Tisza Interfluve, Hungary. - Hydrogeology Journal. DOI: 10.1007/s10040-008-0421-z.

Mádlné Szőnyi, J., Sz. Simon, J. Tóth, Gy. Pogácsás 2005: Felszíni és felszín alatti vizek kapcsolata a Duna-Tisza közi Kelemen-szék és Kolon-tó esetében. (Interrelationship between surface and subsurface waters at the Kelemen-szék and Kolon Lakes, Danube-Tisza Interfluve, Hungary). Általános Földtani Szemle (General Geological Reviews), 30, pp. 93-110. (In Hungarian.)

Mádlné Szônyi, J., J. Tóth, Gy. Pogácsás 2009, this volume: Soil and Wetland Salinization in the frame of the Danube-Tisza Interfluve Hydrogeologic Type Section.

Stiefelhageln, W. 1998: Radio Frequency Elektromagnetics (RF-EM): Kontinuierlich messendes Breitband-VLF, erweitert auf hydrogeologische Problemstellungen. - PhD, Nat. Fakt. der Univ. Neuchâtel, Switzerland. (In German.)

Tóth, J., I. Almási 2001: Interpretation of observed fluid potential patterns in a deep sedimentary basin under tectonic compression: Hungarian Great Plain, Pannonian Basin. - Geofluids, 1, pp. 11-36.

Tóth, Zs. 2007: Felszínalatti víz-tóvíz-üledék kölcsönhatás vizsgálata a Kelemen-szék környezetében (Investigation of groundwater-lake interaction in the case of Kelemenszék Lake). - MSc Thesis, Eötvös L. University, Dept. of Physical and Applied Geology. (In Hungarian.)

Turberg, P., I. Müller, F. Flury 1994: Hydrogeological investigation of porous environments by radio magnetotelluric-resistivity (RMT-R 12-240 kHz). - Journal of Applied Geophysics, 31, pp. 133-143. 